\title{
Użytki, pożytki, porównania
}

\author{
DOI: http://dx.doi.org/10.12775/LC.2015.014
}

Łacińskie słowo cultura oznaczało pierwotnie po prostu u prawę zi e mi, ale już Cycero w Rozprawach tuskulańskich rozszerzył jego użycie na zjawiska intelektualne, nazywając filozofię kulturą ducha. Z tym najwcześniejszym rozumieniem kultury łączyło się wyobrażenie wewnętrznego wysiłku zmierzającego do przekształcenia sfery ludzkiego myślenia w sposób analogiczny do przeobrażeń, jakim ludzka praca poddawała naturalną strukturę gleby, zewnętrzny świat przyrody ${ }^{1}$.

użytek $[. .$.$] zwykle w l m$ «tereny, obszary ziemi będące w uprawie lub n a d a ją c e się do up raw $y \gg[\ldots]$.

pożytek [...] praw. «korzyść uzyskana z rzeczy bez naruszenia jej substancji; przychód »: Przez pożytki w znaczeniu prawnym rozumiemy wszystko to, co: a) ma być oddzielone lub już oddzielone zostało od rzeczy głównej, b) bez zmiany istoty rzeczy głównej, c) jako podstawa stałego i trwałego dochodu z rzeczy głównej, stosownie do jej prze z n a c z e nia. Zoll Prawo cyw. II/ $1,12^{2}$.

Pożytek pszczeli - z a s ó b występujących w przyrodzie surowców pochodzenia roślinnego, wykorzystywanych przez pszczoły jako pokarm oraz służących im do wy twarzania miodu i pierzgi. Są nimi: pyłek kwiatowy, nektar, spadź, a czasem inne soki roślinne. [...] W celu efektywnego wykorzystania p.p. [pożytków pszczelich] stosuje się gos p odarkę w ę d row na ${ }^{3}$.

com-părō 1. (od par) stawiać obok; zestawiać, łączyć; a) naprzeciw siebie postawić [...]; b) porównywać, kłaść na równi, dla porównania zestawiać; c) równo cenić; d) wyrównywać; porozumieć się, ułożyć się, ugodzić, umówić.

com-părō 1. (od parare) przygotować, przyrządzić $[\ldots]$; c) coś urządzić, przygotowania poczynić, tworzyć; [...] e) zaopatrzyć, nabyć, pozyskać, zakupić4.

1 A. Kłosowska, Kultura masowa. Krytyka i obrona, wyd. 2, Warszawa 1980, s. 9. Wyróżnienia - A.F.K., M.W.

2 Słownik języka polskiego, red. nacz. W. Doroszewski, t. 6, Warszawa 1964, s. 1344; t. 9, Warszawa 1967, s. 796. Wyróżnienia drukiem rozstrzelonym - A.F.K., M.W.

${ }_{3}^{3}$ B. Jabłoński, Pożytek pszczeli, [w:] Encyklopedia pszczelarska, red. L. Bornus, Warszawa 1989, s. 161. Wyróżnienia - A.F.K., M.W.

4 Słownik łacińsko-polski, według słownika H. Mengego i H. Kopii, oprac. K. Kumaniecki, wyd. 18, Warszawa 1990 , s. 101-102. 
Porównawcze użytki i pożytki dla dociekań literaturo- czy kulturoznawczych są oczywiste i rozliczne. Badania te poddają efekty ludzkiej aktywności - traktowane jako pewien nieusuwalny, choć wciąż zmieniający się zasób - nieustannej pracy zbierania i kolekcjonowania, wykorzystywania i ugruntowywania, obrabiania i kultywacji (czyli przygotowywania gruntu pod dalszą uprawę), wreszcie też - przeobrażania. W tym procesie grupowanie różnych obiektów i zjawisk w pary lub dłuższe szeregi, konfrontowanie ich, tak by oświetlały się wzajemnie, zestawianie ze sobą dla ujawnienia różnicy albo po to, by mógł wywiązać się między nimi dialog - stanowi element fundamentalny.

Jednoczesne oglądanie tego, co podobne i co różne - jako zamierzona lub pojawiająca się ad hoc procedura poznawcza, porządkująca, wartościująca, ale także jako punkt wyjścia do tworzenia i działania - występuje w najrozmaitszych sferach ludzkiej aktywności i ludzkiego doświadczenia. Do porównań dochodzi w relacjach między kulturami i w efekcie ich wewnętrznego zróżnicowania; w stosunkach między jednostkami i w ich osobniczej autorefleksji; w interakcji różnych sztuk, dziedzin kultury, mediów; między dziełami i twórcami; między tekstami i wewnątrz nich. Zawsze też porównanie pełni jakąś funkcję, czynione jest po coś, z myślą o pewnego rodzaju pożytku, a czasem - po prostu dla zysku (retorycznego, perswazyjnego, politycznego). Cytowana wyżej prawna definicja pożytku podkreśla, że jest nim korzyść uzyskana z rzeczy bez naruszania jej substancji i zgodnie z jej przeznaczeniem. To piękne określenie można właściwie bez zmian odnieść do badania wytworów ludzkiej kultury. Wprawdzie dzisiejsza humanistyka chętnie pomija - jako kłopotliwe i trudne do zoperacjonalizowania - kategorie „przeznaczenia” i „substancji”, można by jednak przewrotnie powiedzieć, że wszystkie, nawet najdziwaczniejsze użytki czynione z dóbr kultury są w nie jakoś in potentia wpisane, skoro są możliwe i skoro przynoszą pożytki.

Seria pozytywnych rozpoznań, od której zaczęliśmy, nie łagodzi drugiej strony komparatystycznego namysłu, na którą składają się: sceptycyzm w kwestii prawomocności czy możliwości porównania, często wyrażane przekonanie - by odwołać się do eseju Lindsaya Watersa $^{5}$ - o niewspółmierności elementów składających się na kulturowy i społeczny pejzaż naszych czasów, poczucie (permanentnego) kryzysu samej komparatystyki, a nawet diagnozy jej śmierci ${ }^{6}$. Wątpliwości w tych ujęciach zdają się dominować nad wiarą w pożytki, jakie mogłyby płynąć z porównania. Jednakże trwająca już dziesięciolecia obecność takich sceptycznych wypowiedzi w dyskursie komparatystyki - która bynajmniej nie przestała się w tym czasie bujnie rozwijać - każe nam podejrzewać, że są one po trosze rytualnym narzekaniem wspólnoty komparatystów, pozwalającym jej się integrować zgodnie z wzorem oblężonej twierdzy (przez okopanie się na „straconych” pozycjach i wzmacnianie więzi wewnętrznych), a zarazem pisać teksty, organizować konferencje, zdobywać granty w imię przełamania kryzysu, wyjścia z rzekomego impasu. Jest jeszcze jedna funkcja tego rodzaju narracji, która prowadzi nas wprost do możliwych pożytków. Otóż pełnią one wobec różnorakich koncepcji funkcję weryfikatora czy falsyfikatora (choćby roboczego, pojmowanego heurystycznie), są wyrazem niezbędnego w poznaniu naukowym sceptycyzmu, który pozwala nam dostrzegać mielizny własnego rozumowania i skłania do ich unikania (mielizna wszak użytkiem nadającym się do uprawy nie jest). Wątpić to

\footnotetext{
${ }^{5}$ L. Waters, Epoka niewspółmierności, tłum. T. Bilczewski, [w:] Niewspółmierność. Perspektywy nowoczesnej komparatystyki. Antologia, red. T. Bilczewski, Kraków 2010.

${ }^{6}$ G. Ch. Spivak, Death of a Discipline, New York 2003. W tłumaczeniu na język polski dostępny jest pierwszy rozdział książki: Przekraczanie granic, tłum. E. Kraskowska, [w:] Niewspółmierność...
} 


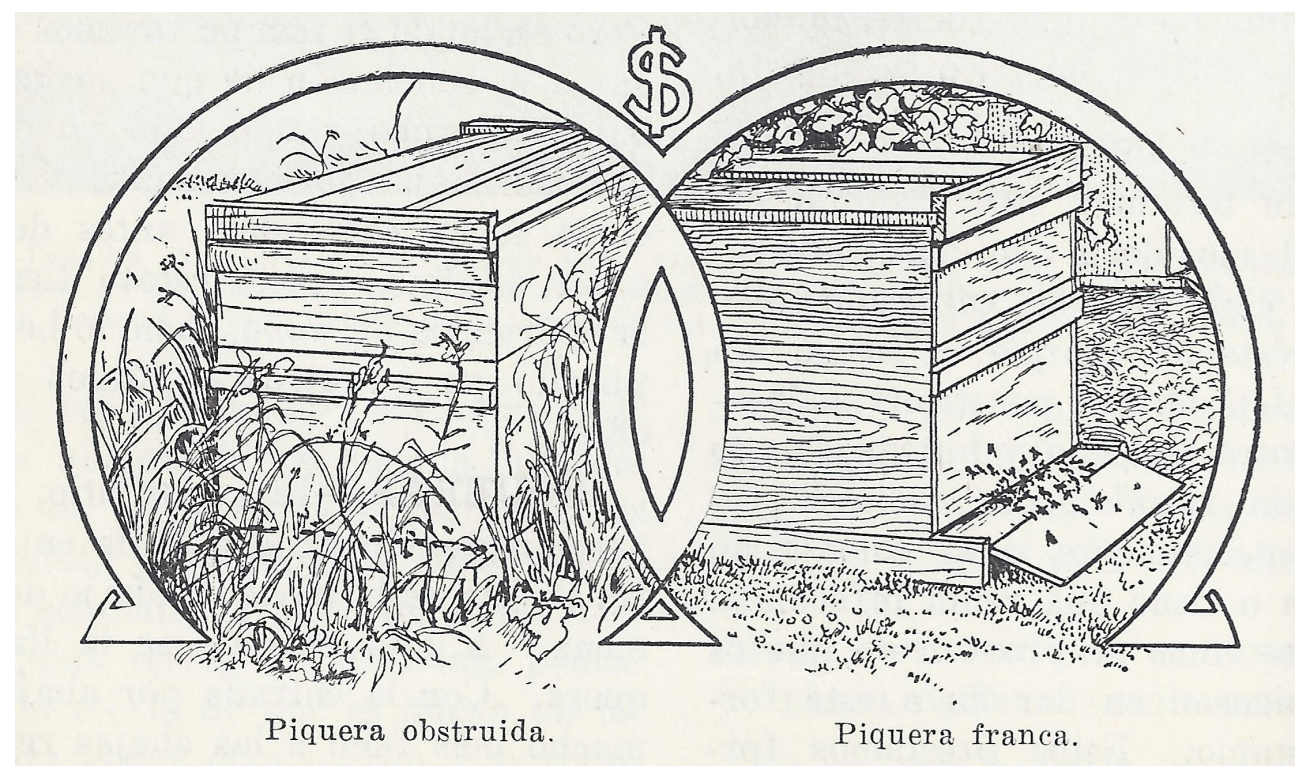

rzecz konieczna, chociaż ważne też, by wątpienie prowadziło w końcu ku jakimś rezultatom pozytywnym.

Henry H. H. Remak pisal: „Komparatystyka literacka to badanie literatury wykraczające poza granice jednego poszczególnego kraju i badanie związków między literaturą z jednej strony a innymi dziedzinami wiedzy i świadomości, takimi jak sztuka (na przykład malarstwo, rzeźba, architektura, muzyka), filozofia, historia i nauki społeczne (na przykład polityka, ekonomia, socjologia), nauka, religia itp. z drugiej strony. Krótko mówiąc, jest to porównanie jednej literatury z inną albo innymi i porównywanie literatury z innymi sferami ekspresji humanistycznej”’ W swej enumeracyjnej definicji, wyliczając, z czym literaturę można konfrontować, Remak zwracał uwagę zarówno na przedmiot (różne dziedziny sztuki), jak i na sposoby oglądu rzeczywistości społecznej, reprezentowane przez różne dyscypliny naukowe.

Blisko pół wieku później Tomasz Bilczewski również wskazywał na kluczową rolę porównawczego zestawienia, widząc w nim element stanowiącej istotę komparatystyki praktyki hermeneutycznej: „Postrzegam komparatystykę jako aktywność interpretacyjną zmierzającą - często poprzez zaskakujące konteksty, w których spotykają się rozmaite nurty humanistycznej refleksji - do zestawienia ze sobą tekstów pochodzących z odrębnych tradycji językowo-kulturowych, jak i z odmiennych sfer ludzkiej ekspresji, czyniącą z gestu przełamywania barier i deklaracji przekraczania różnego typu granic przedmiot swojej szczególnej uwagi. Widzę w niej - często odświeżającą utrwalone przez tradycję sposoby czytania - praktykę lekturową, dążącą do świadomego zbliżania, nieraz bardzo odmiennych, zjawisk literackich i kulturowych; swoistą hermeneutyczną szkołę eksploracji tego, co nam się wymyka i poprzez dążenie do rozumienia, które nigdy nie jest procesem skończo-

7 H. H. H. Remak, Literatura porównawcza - jej definicja i funkcja, tłum. W. Tuka, [w:] Antologia zagranicznej komparatystyki literackiej, red. H. Janaszek-Ivaničková, Warszawa 1997, s. 25. 


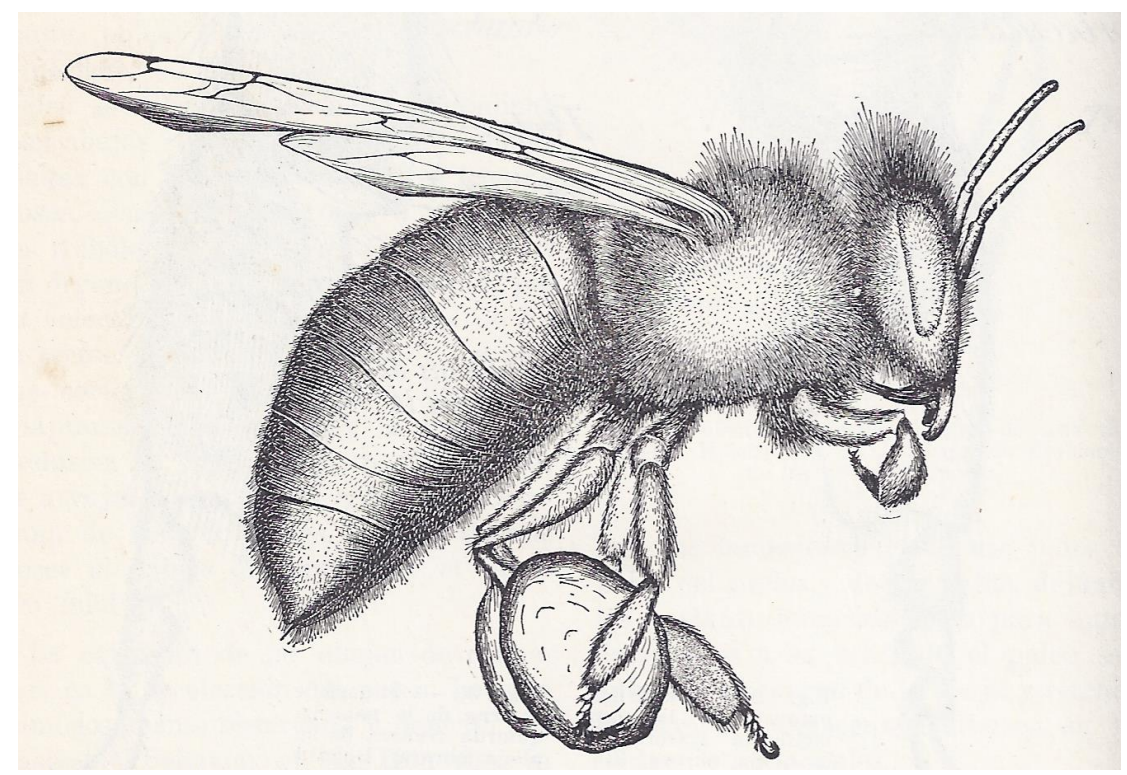

nym, wymaga wykroczenia poza obszar naszych przyzwyczajeń”. To przejście od definiowania p o l a komparatystycznego do prób opisania p r a k t y k i badań porównawczych jest znaczące, odpowiada przemianom, które zaszły w łonie dyscypliny w drugiej połowie XX wieku i w początkach wieku XXI.

Haun Saussy wskazuje na jeszcze jedno przesunięcie, które charakteryzuje postmodernistyczne postrzeganie komparatystyki i w ogóle humanistyki, a dokonało się w ramach teorii i filozofii interpretacji - przesunięcie w kierunku idiosynkratyczności. Jego zdaniem atrakcyjność dociekań porównawczych polega między innymi na tym, że „każdy projekt komparatystyczny jest do pewnego stopnia eksperymentem" ${ }^{\prime 2}$ zakorzenionym w wizji, doświadczeniu, wiedzy i kulturze konkretnego badacza czy badaczki. Jego powodzenie zależy nie tylko od tego, czy proponowane zestawienia badanych przedmiotów są przekonujące, czy nie dałoby się dojść do określonych wyników lub interpretacji, „patrząc na każdy z tych przedmiotów z tradycyjnej dla jego dyscypliny perspektywy" ${ }^{10}$, lecz także od indywidualnego piętna pozostawionego przez osobę, która dokonuje porównania. Przy takim ujęciu obiektem refleksji mogą stać się już nie tylko badane przez komparatystów przedmioty, ale i same praktyki porównania, dokonywane przez różniące się między sobą podmioty, wychodzące z odmiennych punktów i rozmaicie zaangażowane w swoją działalność.

Komparatystyka współczesna wraca do sporu na temat miejsca, jakie w jej dyskursie zajmują literatury narodowe, do opozycji tego, co narodowe, i tego, co powszechne, uniwersalne, światowe. Wbrew marzeniom tych, którzy literaturę (i jej historię) chcieliby po-

8 T. Bilczewski, Komparatystyka i interpretacja. Nowoczesne badania porównawcze wobec translatologii, Kraków 2010, s. 29.

${ }^{2} \mathrm{H}$. Saussy, "Wyborny trup" pozszywany ze świeżych koszmarów. O memach, pszczelich rojach i samolubnych genach, tłum. E. Rajewska, [w:] Niewspółmierność..., s. 222. Pokrewieństwo pszczelich rojów Saussy'ego i naszych pożytków pszczelich jest czysto przypadkowe, być może wszakże na poziomie analizy używanych metafor ta koincydencja warta jest głębszego namysłu.

${ }^{10}$ Ibidem. 
strzegać wyłącznie narodowo, niepodobna dziś zamknąć ją w etnicznie, językowo czy państwowo wyznaczonych granicach. Literatura jest transgresyjna sama w sobie, przekracza, wędruje, z pożytkiem dla siebie samej oraz innych literatur i kultur, dla czytelników niezależnie od ich tożsamościowego przypisania - i wymaga stosowania przez literaturoznawców podobnej „gospodarki wędrownej”. David Damrosch pisze: „Literatura światowa to nie ustalony kanon tekstów, lecz tryb lektury: forma bezstronnego zaangażowania w światy poza naszym własnym miejscem i czasem" ${ }^{11}$. Komparatystyka - co widać w nowych projektach areałowych czy regionalnych, światowych, globalnych, inter/planetarnych - wyzbyła się utopijnych roszczeń do powszechności czy uniwersalności, nie wyrzekając się przy tym tego, co narodowe, dostrzegając nieodzowność etniczno-regionalnej perspektywy czytelniczej, umocowania w języku i geograficznie zlokalizowanej kulturze. Taka komparatystyka nie absolutyzuje i nie esencjalizuje ani tego, co lokalne, narodowe, regionalne, ani tego, co światowe. Staje się praktyką czytania i badania tekstów w nowy sposób - z pożytkiem dla siebie samej/samego, ze zgodą na użytek, jaki czytelniczka/czytelnik zechce z czytania zrobić. Ta praca ma charakter nieustannego przeobrażania prywatnego kanonu, jest wszakże zawsze wspólnotowo, a zatem i kulturowo, zakorzeniona.

Stawianie pytań podstawowych pozwala dostrzec i sproblematyzować to, co na co dzień zbyt łatwo bywa uznawane za oczywistość. Projektując ten tom, chcieliśmy poddać pod rozwagę kategorię dla komparatystyki kluczową, lecz w warunkach inflacji nowych trendów często zapoznawaną. Zaproszonych autorów zachęcaliśmy do zastanowienia się nad statusem i możliwościami porównania jako narzędzia badawczego stosowanego w literaturoznawstwie, kulturoznawstwie, translatologii, lingwistyce, filozofii etc. Autorzy Pożytków z porównania szczególnie uważnie przyglądają się literaturze jako tej części kultury, w której najwyraźniej do głosu dochodzi jej samoświadomość pojmowana jako swoisty metajęzyk kultury ${ }^{12}$.

Komparatystyka naszym zdaniem znajduje się - a przynajmniej powinna się znaleźć w centrum humanistycznego namysłu, zwłaszcza w dobie globalizacji i internetu, przybierających na sile migracji i wielokulturowości. Uważamy, że w takim momencie warto sięgnąć do tradycji tej dyscypliny, do rejonów rzadko dziś eksplorowanych, nurtów niedostrzeganych ${ }^{13}$, te zaś skonfrontować z nowymi wyzwaniami teoretycznymi i metodologicznymi oraz z nietradycyjnymi polami badawczymi. Jest to założenie, które legło u podstaw niniejszego tomu, pewien gest metodologiczny, poprzez który zderzamy ze sobą, czy raczej pozwalamy się spotkać temu, co dawne i tradycyjne, niekiedy już wyparte, z tym, co nowoczesne i co stanowi nowy kanon myślenia komparatystycznego.

Do kluczowych kontekstów współczesnej komparatystyki literackiej należą postkolonializm, translatoryka i literatura światowa. Można by tu też dodać coraz silniej obecną nie tylko w literaturoznawstwie, ale humanistyce jako takiej problematykę ekologiczną i post-

11 D. Damrosch, Dość czasu i świata, tłum. A. F. Kola, „Teksty Drugie” 2014, nr 4, s. 101 (w oryginale tekst podkreślony).

12 Por. M. Dąbrowska-Partyka, Literatura jako metajęzyk kultury, „Studia z Filologii Polskiej i Słowiańskiej” 2005, t. 40 .

${ }^{13}$ Na pożytki płynące z takiej praktyki od lat wskazuje w Polsce Danuta Ulicka, zob. D. Ulicka, Literaturoznawcze dyskursy możliwe. Studia z dziejów nowoczesnej teorii literatury w Europie Środkowo-Wschodniej, Kraków 2007; eadem, Zwrot archiwalny (jak ja go widzę), "Teksty Drugie” 2010, nr 1/2; zob. także A. F. Kola Nie-klasyczna historia teorii literatury Europy (Środkowo-)Wschodniej, „Teksty Drugie” 2009, nr 4. 
humanizm, kognitywistykę i filiacje $\mathrm{z}$ neuronaukami oraz digital humanities, a wszystko to zaprawione dominacją Global English i akademii anglosaskiej. Pożytki z porównania przyjmują inny punkt wyjścia, w punkcie dojścia stykając się wszakże ze wskazanymi powyżej punktami węzłowymi współczesnych badań porównawczych. Zgromadzone w tomie teksty pokazują możliwość dialogu między różnymi tradycjami: formalistyczno-strukturalną i poststrukturalistyczną, nauką o literaturze i krytyką literacką, badaniami nad retorycznością i studiami intersemiotycznymi. Ujęcia teoretyczne uzupełniają się tu z historycznymi, spojrzenie szerokie - z ćwiczeniem komparatystycznego close reading. Efekt tych zestawień wyraźnie wskazuje kierunek dalszych poszukiwań, w których komparatystyka, podejmując próby definiowania na nowo swoich rudymentarnych problemów, winna kierować uwagę na wciąż możliwe do podjęcia propozycje minionych, zdawałoby się, szkół i kierunków literaturoznawczych. Wierzymy, że połączenie form i wątków tradycyjnych ze współczesnymi pokazało siłę tkwiącą w komparatystyce i że będzie stanowić zachętę do dalszych poszukiwań.

Niniejsza publikacja jest efektem działalności Pracowni Komparatystyki Literacko-Kulturowej, funkcjonującej na Wydziale Filologicznym Uniwersytetu Mikołaja Kopernika od 2011 roku. Zgodnie z nazwą pracowni, a wbrew formułowanym z różnych stron obiekcjom, jesteśmy przekonani, że podejście kulturowe czy kulturoznawcze nie musi ani wykorzeniać praktyki literaturoznawczej, ani też unieważniać czy deprecjonować literatury jako takiej ${ }^{14}$. Nastawienie kulturoznawcze otwiera jednak na nowe spojrzenie na literaturę, pozwala włączyć zjawiska literackie w kontekst całej kultury i ujmować je w szerszej niż dotąd perspektywie - jest to atut trudny do przecenienia.

Tom nie jest i nie miał być zwartą propozycją metodologiczną ani manifestem teoretycznym, lecz próbą zebrania różnych głosów wybrzmiewających w przestrzeni porównawczego namysłu nad literaturą i kulturą. Jednak sięganie do tradycji - na przekór tendencjom dominującym obecnie nie tylko w komparatystyce - i zderzanie jej z nowymi kierunkami myślowymi jest oczywiście pewnego rodzaju manifestacją. Dobór tekstów w prezentowanej publikacji wyraża bowiem przeświadczenie, że w dialogu z minionym można wciąż wiele odkryć i że warto trochę spowolnić spiralę zwrotów badawczych i pogoni za nowością, w którą wpadła współczesna humanistyka.

Adam F. Kola*, Marcin Wotk

14 Por. M. Riffaterre, O wzajemnym uzupełnianiu się komparatystyki literackiej i studiów kulturowych, tłum. R. Sendyka, w: Niewspółmierność....

* Autor jest adiunktem w Katedrze Filologii Bałkańskiej, członkiem Pracowni Badań nad Pamięcią Zbiorową w Postkomunistycznej Europie (POSTCOMER) i Pracowni Komparatystyki Literacko-Kulturowej UMK, przewodniczącym Polskiego Stowarzyszenia Komparatystyki Literackiej. Otrzymał stypendia w kilku programach Fundacji na rzecz Nauki Polskiej oraz stypendium MNiSW dla wybitnych młodych naukowców (2012-2015). Był finalistą Nagrody Naukowej „Polityki” w kategorii nauki humanistyczne (2014). Opublikował m.in. książki Słowianofilstwo czeskie i rosyjskie w ujęciu porównawczym (2004) oraz Europa w dyskursie polskim, czeskim i chorwackim. Rekonfiguracje krytyczne (2011); współredagował tom Filozofia i etyka interpretacji (2007). E-mail: adamkola@umk.pl.

${ }^{* *}$ Autor jest adiunktem w Instytucie Literatury Polskiej i kierownikiem Pracowni Komparatystki Literacko-Kulturowej UMK. Opublikował książki Tekst w dwóch kontekstach. Narracja pierwszoosobowa w powieściach Kazimierza Brandysa (1999) i Głosy labiryntu. Od "Śmierci w Wenecji” do „Monizy Clavier" (2009), a także artykuły na temat autobiografizmu w literaturze XX w., groteski literackiej, form narracyjnych oraz twórczości pisarzy współczesnych, głównie polsko-żydowskich. Jest członkiem Polskiego Stowarzyszenia Komparatystyki Literackiej oraz European Association for Holocaust Studies. E-mail: wolkmarc@umk.pl. 